JOURNAL OF SECURITY AND SUSTAINABILITY ISSUES

ISSN 2029-7017 print/ISSN 2029-7025 online

2019 June Volume 8 Number 4

http://doi.org/10.9770/jssi.2019.8.4(1)

Scopus

\title{
OIL, DEVELOPMENT, AND MILITARY EXPENDITURE: A PANEL DATA EVIDENCE FROM THE MIDDLE EAST
}

\author{
Md Riyazuddin Khan', Mohammad Imdadul Haque ${ }^{2}$ \\ ${ }^{1}$ B.R.Ambedkar College, Delhi University, India. ${ }^{2}$ Prince Sattam Bin Abdulaziz University, Saudi Arabia \\ E-mails: ${ }^{1}$ riyazdse@gmail.com; ${ }^{2}$.haque@psau.edu.sa (Corresponding author)
}

Received 15 November 2018; accepted 15 May 2019; published 30 June 2019

\begin{abstract}
In the Middle East, vast oil reserves led to economic modernization and prosperity in the region. However, it is one of the most conflict-prone regions. This paper studies the relationship between military spending, oil and development in Middle Eastern countries using a panel data fixed effect for country-level observations over the period 1986-2016. The relationship between development and conflict will not be uniform throughout the region. Therefore, to test this hypothesis, the study categorized oil exporting countries into three parts that are countries with above average oil export, below average oil export and no oil export. The estimates show a significant reduction in military spending over time and the most declines were observed in the countries where oil export is above average than the Middle East. The results indicate a significant inverse relationship between the military spending with exports and oil rents in overall Middle East analysis and for countries whose average oil export is greater than the Middle East. It is also found that the military burden adversely affects economic growth across all the model specification. However, military spending is declining over time which indicates that there is a reverse causality between development and conflict. It is crucial finding in the context of peace and development literature
\end{abstract}

Keywords: Middle East; Oil; Development; Military expenditure; Panel data

Reference to this paper should be made as follows: Khan, M.R and Haque, M.I. (2019). Oil, development, and military expenditure: a panel data evidence from the Middle East, Journal of Security and Sustainability Issues 8(4): 549-568.

http://doi.org/10.9770/jssi.2019.8.4(1)

JEL Classifications: F52, H56, O11

\section{Introduction:}

Middle East is considered as the "centre of gravity" for the world oil industry. The security and sustainability issues of this region are unique in nature (Sulphey and Alkahtani, 2017). Oil is one of the essential and important aspects in both foreign and domestic politics of every country for both oil exporter and importers. The discovery of oil in the Middle East and its use has a significant result on economic development. Before oil exploration, the Middle East was a weak region, "deprived economically with a very limited resource" (Gregory 1994). Before 1950, the countries in the regions unveiled some of the lowermost levels of socioeconomic development in the world (Yusuf, 2004). The start of the 20th century has become a central point in the development of the whole region. Discovery of oil in the region as well as its utilization has changed the situation intensely and played an essential role in supporting the growth model in both the oil exporting and non-exporting states (Chaudhry, 1997). The 1960s observed enormous public investments in development indicators such as education, health, infrastructure as well as state-owned enterprises in the Middle East. These efforts provided a boost to industrialization which boosted economic growth (Yusuf, 2004; Haque and Khan 2019).

Studies have opined that studying regional economy is an important pre-condition to look at overall development (Pietrzak et al., 2017; Prause et al., 2019; Zeibote, 2019; Humbatova et al., 2019). Middle East region has 
perceived substantial progress in economic, political as well as social spheres since the discovery of oil. It played a major role in shaping the politics, development of the economy, and foreign relations over the past century. Most of the oil producing countries in the world are in the Middle East region. According to recent estimations, $81.89 \%$ of the world's oil reserves are in OPEC Member countries, with the majority of its reserves in the Middle East. The regions have enormous oil reserves, which accounts for 66 percent of the world's supply. There is a understanding that the massive oil reserves led to economic transformation and wealth in the region, however, on the other hand, it had also created weak states that are independent of societal demands, political responsibility and transparency (Schwarz 2008).

Due to the importance of oil, the political turmoil in the Middle East region is a significant disruption factor in the international oil market (Darbouche and Fattouh 2011; Das et al. 1990; Masood et al. 2019).

The armed conflicts in the Middle East in which Western powers intervened, such as the Lebanese civil war (1975-1990), Gulf War of 1991, Iraq War of 2003, and the 2011 Libyan War, resulted in the most significant oil price fluctuations during the 1990s and 2000s (Ji and Guo 2015; Zhang et al. 2009). These conflicts were closely linked to the strategic goal of stabilizing the crude oil markets of major energy consumers, including the U.S., the world's largest oil consumer. Among the significant armed conflicts fought since World War II, over half it involved the Middle East. Geopolitical conflicts in the Middle East are a considerable disruption factor in the crude oil market. Many studies consider the effects of political disputes in the Middle East on oil price volatility and behavior (Coleman 2012; Darbouche and Fattouh 2011; Das et al. 1990; Zhang et al. 2009).

Post-conflict retrieval depends on economic and institutional development of the country, the structure of the economy, the length of the war, and the involvement of the international community. The speediness of economic retrieval was wide-ranging significantly across countries. In Lebanon, it almost took 20 years post-war for the real GDP to improve to its pre-war level, it took seven years in Kuwait, and one year in Iraq (Sab, 2014). However, Lebanon has not yet completely returned to its pre-war level, and the existing ongoing difficult security and political environments continue to load down on growth. In Kuwait, just after two years, real GDP per capita was above its pre-war level. Iraq, it took three years for real GDP per-capita to completely improve to its pre-war level. Despite robust real GDP growth rates in Iraq, economic governance has worsened, resulting from an increasingly difficult political process and worsening security conditions (Sdralevich and others, 2013).

\section{Background of the study: Oil reserves, trends, exports and trading partners in the Middle East}

Saudi Arabia has the most massive stockpile of crude petroleum among the Middle Eastern countries. It has almost 32 percent share, followed by Iran (16\% share), Iraq (14\%), Kuwait (13\%), United Arab Emirates (12\%), Qatar (3\%). These six nations in the Arabian Peninsula constitute almost $90 \%$ of the total reserve of Crude petroleum available in the Middle East region. Libya amongst the North African countries has the highest reserve share, nearly $5 \%$ of the total crude reserve available till date in the region followed by Algeria (3\%), and Egypt (1\%). The remaining $1 \%$ of the crude reserve is shared by Oman, Bahrain, Turkey, Syria, Israel, Jordan, Yemen, Tunisia, and Morocco). Rest of other countries in the region have a negligible share of Crude reserve (OPEC 2017). With changing technology and to attain economic, social and political benefits, the governments of the Middle Eastern region has tried their best to identify new areas of crude petroleum reserve, increasing in their existing production unit to meet the growing national and international demand for oil and its products. The reserve for crude oil has seen to be improved since 1990 in countries of Algeria, Iran, Iraq, Libya, and Qatar. However, Saudi Arabia the big oil giant among the Middle Eastern countries has seen a decreasing reserve. The reserve for crude was almost constant in countries like Iraq, Kuwait and UAE. The sharpest increase in the reserve can be observed in Iran and Qatar. The most acute decrease in the reserve can be noticed in Saudi Arabia among the major oil producing countries in the Middle East. Amongst the North African countries of the Middle East, Libya and Algeria have witnessed a sharp increase in the reserve since 1990 followed by Tunisia. However, Libya and Morocco have seen a decreasing reserve of crude since 1990 (Khan, 2015). 
Saudi Arabia oil reserve had increased significantly since 1990 because of the identification of the new areas of the oil reserves, but from 2000 till 2009 the amount of reserve has decreased because of the growing production of oil from existing reserve to meet the increasing demand for the world market and not many new areas of the reserves were identified and explored. However, until Saudis have the most massive stockpile of Crude Oil, almost 32 percent of the total in the Middle East region. However, Iran had a sharp increase in reserve recently. Their stable government, internal peace, and their favorable government policies and their technological advancement have made them to explore new areas and add to their existing crude reserve (Khan, 2015).

Iraq has also witnessed an increase in its reserve after 1990. It saw significant growth in 2000, but the rates of increases were prolonged from 2000 to 2009. After the gulf war in 1990, the US and its allied countries that got significant gain after the war has set up many new companies for oil exploration, even the government wanted a vast amount to reconstruct the devastation done during the war, and this has resulted in an aggressive policy of oil exploration and identification of reserve regions by the local Iraqi government. After the US war on Iraq in 2003 and removal of Saddam Husain government, Iraq has witnessed an almost internal civil war situation, the growing insurgency, and ethnic conflicts, till the execution of Saddam.

This growing internal conflicts and instability in the country have hampered the developmental work and, in the identification, and exploration of new crude reserve in the country. Kuwait has an abundance of the crude reserve, it holds about 13 percent of the total oil reserve available in the Middle East, being small in area compared to other oil giants in the region like Saudi Arabia, Iran, and Iraq. It has witnessed an increasing trend in recent years. The United Arab Emirates is also naturally endowed by a surplus abundance oil reserve. Small in areas, this oil has boosted its economy. However, it has witnessed a decreasing crude reserve since the 1990s. Qatar is the only country in the Middle East which has seen an enormous increase in its existing oil reserve.

Like Iraq, Kuwait, Oman, Algeria also observed an increase in export for crude in the international market since 2000. Some countries also find a decrease in their current export; such as Iran, Iraq, Oman, Syria, and Yemen. Since the last 30 years (1990-2009), Algeria, Kuwait, and Saudi Arabia were the countries in the Middle East region who witnessed an increasing trend in their export since 1990. Saudi Arabia, UAE, Iran, Iraq, Kuwait, Oman, and Qatar are major crude petroleum exporting countries in the world. They have such surplus that they have never imported crude oil. While there are such countries in the Middle East, who do not have surplus crude oil to export after meeting their domestic need and have never exported the Crude to the world market, they are the major importing countries of Crude Petroleum in the Middle East region, namely; Israel, Cyprus, Jordan, Lebanon, Morocco and Turkey (Khan, 2015).

Energy is a crucial element in national security (Traversari, 2017; Rogalev et al., 2018; Dźwigoł et al., 2019; Prakash and Garg, 2019). It has always been about oil when it comes to the Middle East. Oil has given economic independence to try development policies and to establish political bonds that are excluded from poorer states. It has furthermore served as an opportunity that is military attributes of power, making other nations to rescrutinize their foreign policies in the light of long-term economic interests. Thus, it has assisted in breaking down the post-war supremacy of the super-powers by providing encouragements for greater independence on the part of their association partners and extra-regional clients and their dependencies. Revenues from oil allowed Middle East governments to modernize countries through industrialization, economic, and social development.

The political stability is other significant concern in the middles east. Most of the countries fail to provide stable government. Some key parameters of governance indicators in the region included corruption control, government efficiency, political stability and absence of violence. Most of the countries are not able to achieve in all the three governance indicators. Although courtiers like Cyprus, Kuwait, Oman, Qatar, and United Arab Emirates performs good in all aspects of governance, and the rest of all countries have not performed throughout. For example, countries like Bahrain, Israel and Jordan have advantages in controlling the corruption and able to achieve effective government but they have lost control in achieving political stability and absence violence (Khan, 2015). 


\section{Military Expenditure and Economic Development}

Oman and Saudi Arabia are the largest military spenders in the region and ranks third and fourth after the US and China. Their military spending increased by 74 percent, between 2008 and 2015, and attained a peak of $\$ 90.3$ billion. UAE is the third largest military spender in the region. Considering ongoing military operations and large arms procurement projects, it is realistic to assume that its military expenditure remains the same. By 2014 Iran's military expenditure had declined steadily from its peak in 2006. However, since 2014 the Iranian economy has profited from the gradual lifting of the European Union and United Nations sanctions, which in turn facilitated an increase in military spending. Following a peak in Israel's military spending in 2014-15, which coincided with its military operations in Gaza in 2014, its expenditure dropped. Seven of the ten countries in the world with the maximum military spending in 2017 are in the Middle East. Oman spends around 12 percent of GDP on military spending, while Saudi Arabia (10 percent), Kuwait (5.8 percent), Jordan (4.8 percent), Israel (4.7 percent), Lebanon (4.5 percent) and Bahrain (4.1 percent) respectively (Tian, N, 2018).

In figure 1, it is plotted the Locally Weighted Scatterplot Smoothing (LOWESS) graph, and see that military expenditure for most of the countries such as Decline: Qatar, Syria, Israel, Cyprus, Egypt, Jordan, Kuwait, Libya, military expenditure is declined with the most significant decrease in Qatar. Some countries also have increased their military spending such as Algeria, Iraq, and Oman, while some other countries have somewhat stable military spending since 1986 to 2016.

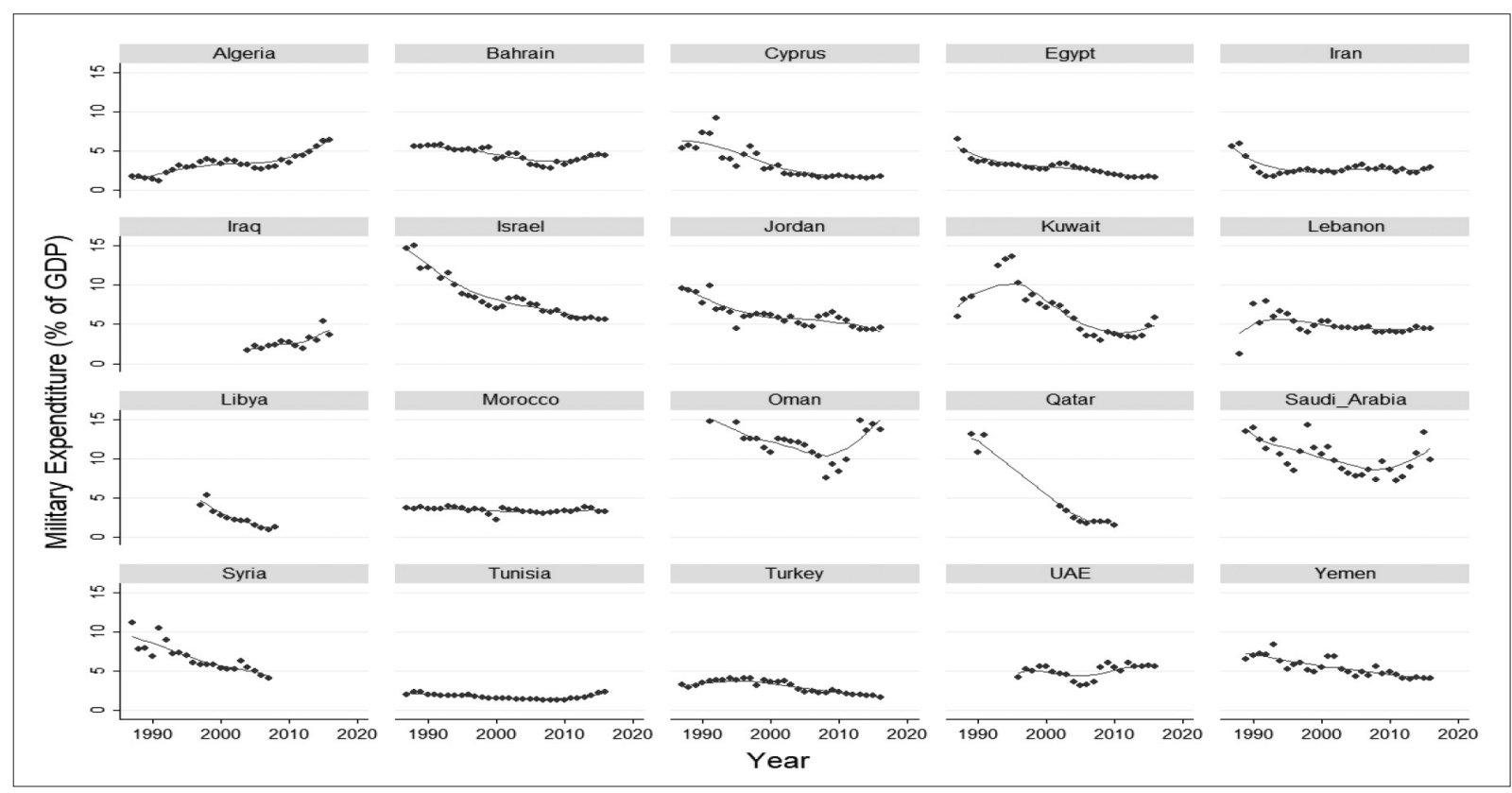

Figure 1: Country-wise military expenditure (\% of GDP) from 1986-2016

Source: Authors' calculation

The GCC countries witnessed a significant rise in military expenditures in the recent decades is a result of several many interconnected factors. Among these factors, the real threats to their security are such as armed conflicts in the region, domestic disturbance, and the rising military influence in the Middle East. A significant increase in military spending in the Arab Gulf states initiated during the mid-1980s, sparking an upward trend, despite some interrupted fluctuations. The Iraq invasion of Kuwait in 1990 encouraged not only Kuwait but also Saudi Arabia and the U.A.E., to increase their military spending significantly. However, after 1992, most of the Gulf countries slightly reduced their military spending. The increase in military expenditure soon re-emerged in the region. Saudi Arabia increased its yearly spending on the military from $\$ 26.5$ billion to more than $\$ 32$ billion between 1997 and 2001, while the U.A.E. increased their expenditure from $\$ 6$ to $\$ 10$ billion in the same period. During the same timeframe, Bahrain roughly doubled its military spending, while the spending of Kuwait and Oman remained on the same level. Meanwhile, Qatar's defence spending decreased. 


\section{Review of Literature:}

Studies have identified not only economics and human development but also politics as a threat to sustainable economic development, highlighting the role of factors like natural resources, economic situation, and geolocation (Katina et al., 2018). Studies have highlighted the importance of both economic and political security (Stukalo et al., 2018). Studies have identified an 'asymmetry of economic interest and geopolitics' gobally (Guliyera et al., 2018). Studies have identified a recent trend in literary circles wherein 'sustainability of militarization' is being discussed as increased militarization leads to more energy consumption and increased income inequality (Smaliukiene, 2018). Studies have also associated inverse trends in human capital with a wide range of threats to security (Shevyakova and Petrenko, 2018; Tvaronavičienè, 2018).

Numerous studies have investigated the economic impact of conflicts. Collier (1999) observed that civil wars consequence in the decline in real GDP per-capita. Gupta et al. (2002) for the low- and middleincome countries found that conflicts caused higher inflation and lower economic growth, tax revenues and investment. Addison et al. (2002) found that economic development is vulnerable to conflict and reduces the demand for domestic currency, which results in weak economic instruction leads to harms country economic growth. Others have studied the spillover effects of conflict in neighboring countries. Ades et al. (1997) got that political uncertainty in neighboring countries harmed a country's economic growth. Similarly, DeGroot (2010) in Africa found that bordering countries; have an adverse spillover from conflicted countries, while non-bordering countries might have a positive overflow. Conflict is a serious security and sustainability issue (Kazansky and Andrassy, 2019).

There are many studies which explore the association between military spending and economic growth. Benoit's (1973) influential study, recommends that military expenditure have positive effects on economic development. Though there are alternative opinions concerning the adverse impact of military expenditure, however, new studies appear to be providing an adverse consequence of military spending on economic growth (Dunne and Tian, 2013). It has been said that an increase in defense expenditures possibly will hinder economic growth by pushing out investment on health, education and infrastructural improvement.

Lebovic and Ishaq (1987) for 20 Middle Eastern countries reported an adverse effect of military expenditure on economic growth for the period 1973-1982. Abu-Bader and Abu-Qarn (2003) for Egypt, Israel, and Syria, and DeRouen (2000) for Isreal finds that the defense expenditures hinder economic growth while positive effects of Turkish defense spending advocated by Sezgin (2000) and Yildirim, et al. (2005). For Turkey, Karagol (2006) finds a definite connection between defense spending and external debt, and, Dunne et al. (2001) found an adverse relationship between economic growth and defense spending. Brzoska (1983) and Looney \& Frederiksen (1986) recommend that borrowing finance for military spending will harm the country's progress if it faces restrictions on international borrowing. Brzoska (1983) also estimated that the spending on arms was accountable for $20 \%$ to $30 \%$ of external debt in developing countries. A study from six Middle Eastern countries, it is estimated that a $1 \%$ increase in military expenditure results in between a $1.1 \%$ and $1.6 \%$ increase in external debt in the long run, and it increases external debt by $0.2 \%$ in the short run (Smyth and Kumar, 2009).

Some studies recommend that increase in government spending on the military may decrease the risk of civil conflict beginning (Hegre and Sambanis, 2006; Basedau and Lay, 2009; Taydes and Peksen, 2012). In the oil and gas-rich countries, conflicts are less expected when military expenditure is more. However, countries with low natural resources, an increase in military expenditure is associated with a greater risk of conflict. While greater spending on education, health, or social security is associated with a lesser risk of conflict, regardless of the level of oil revenue (Bodea et al. 2016). Henderson and Singer (2000) claim that higher military expenditure crouds-out social spending, economic growth, and investment.

Dunne and Uye (2010) in a review of 102 studies show that adverse effects of military spending on growth in $35 \%$ of case studies and only $20 \%$ found of them have positive effects, while for over $40 \%$ case studies found unclear results. Using data for 106 countries from 1988-2010, the study finds that military burden harms growth in both 
the short and long run. For Lithuania, Rackauskas and Liesionis (2013) found that the relationship between government expenditure on defence, safety, and public order impacts economic situation. However, others suggest that for some countries military spending has no significant effect on growth (Dunne and Tian, 2015).

For Algeria, Duella (2014) for 1988-2010, suggests that there is unidirectional causation running from military expenditure to economic growth, with overall adverse effect in the long-run. For Jordan, Abu Al-Foul (2014) for the 1988-2007 period also finds unidirectional association running from military expenditure to economic growth. More recently for Jordan, Abu-Ghunmi, D., \& Larkin, C. (2016) finds that during 24 years of regional chaos, the country lost $40-72 \%$ of its 2012 gross domestic product (GDP). Furthermore, it has also lost US\$2.3 billion of foreign direct investment (FDI). Al-Jarrah (2005) for Saudi Arabia 1970-2003 period, find bidirectional causation among military expenditure and economic growth and unidirectional from non-oil economic growth to defense expenditure; with the adverse effect of defense spending in the short run. A more recent study from Saudi Arabia, suggests that defence expenditure harms economic growth, which worsens during times of conflicts (Serkan et al. 2016).

\section{Research objective and methodology:}

In the academic world, the substance of studies regarding the military expenditure and growth relationship, in general, more for NATO, OECD, and Latin American countries. Though Middle East nations spend a greater share of their GDP in defence, yet there were very few studies on the whole Middle East region. This paper studies the effects of military expenditures on economic growth for Middle Eastern countries using the longitdutional data for the period 1986-2016. For this analysis, panel data sets are created for 20 major countries to examine the relationship between the indicators of conflict and the indicators of development. Ideally, data needed on incidents of terrorist killing normalized by the population as the indicator of conflict. Because of data constraints, this paper used a share of Military expenditure to Gross Domestic Product as the proxy for conflict. For the indicator of development, this paper used the Gross Domestic Product (GDP), Export, Import, Oil Rent, etc. The association between military expenditure and economic growth is examined by using panel data fixed effect regression model.

Military expenditures data obtained from the Stockholm International Peace Research Institute (SIPRI), which comprises total current and capital expenditures on the armed forces. These expenditures include military and civil staffs, including retirement pensions and social services of military personnel; operation and maintenance; procurement; research and development; and military aid. However, it excluded civil defense and current expenditures for previous military activities, such as for veterans' benefits, retirement, conversion, and demolition of weapons. This measure is advantageous because it negates the differences between economies. Besides, it should also measure the comparative rate of participation in the conflicts that they join because if a country is severely involved in a conflict, it follows that their military spending of GDP will increase. Gross domestic product (GDP) is collected from the world development indicator (WDI) of the World Bank. Oil rents are taken by WDI; it is the difference between the value of crude oil production at world prices and total expenses of production. It also measures wealth in some aspects, and it can be assumed that wealthier countries will have more oil rents as a percent of GDP.

Our empirical strategy exploits the variation in the indicators of development over time to examine the association of Military Expenditure with GDP. The study used a panel framework with the fixed effect specification to pin down the relationship between these indicators. In the second stage, it classified Middle East countries into three groups based on the table below; where the first group comprises of those countries where average oil export is higher than the Middle East average. The second group comprises of those countries where average oil export is lower than the Middle East Average. The third group comprises of those countries where average oil export is almost zero. This strategy helps in empirically testing the role of oil in the Middle East conflict.

The study used the following panel data fixed effect estimation equations to study the relationship between Military Expenditure, export, oil rent, and GDP: The functional estimate takes the form: 


$$
\begin{aligned}
\operatorname{Ln}(Y)_{i t}= & \beta_{0}+C_{i t}+T_{i t}+u_{i t} \quad(1) \\
\operatorname{Ln}(Y)_{i t}= & \beta_{0}++C_{i t}+T_{i t}+\beta_{1} \ln (\text { export })_{i t}+u_{i t} \quad \text { (2) } \\
\operatorname{Ln}(Y)_{i t}= & \beta_{0}++C_{i t}+\beta_{1} T_{i t}+\beta_{1} \ln (\text { export })_{i t}+\beta_{2} \ln (\text { oilrents })_{i t}+u_{i t} \\
\operatorname{Ln}(Y)_{i t}= & \beta_{0}++C_{i t}+\beta_{1} T_{i t}+\beta_{1} \ln (\text { export })_{i t}+\beta_{2} \ln (\text { oilrents })_{i t} \\
& +\beta_{3} \ln \left(g d p_{-} \text {growth }\right)_{i t} u_{i t}(4)
\end{aligned}
$$

Where $\operatorname{Ln}(Y)_{i t}$ is the dependent variable which is the military spending (percent of GDP), subscript $\mathrm{i}$ and $\mathrm{t}$ denotes country and time,,$\beta_{0}$ is the intercept and $\beta_{i}$ is the estimated coefficients of the independent variables (natural log of percent of GDP export, percent oil rents and percent growth rate of GDP), $C$ is the country fixed effect which captures the heterogeneity across Middle Eastern Countries and $T$ is the time fixed effect which captures the technological change and $u$ is the error term. The study used four different models based on the country classifcation based on the oil exports into three groups discussed above to explore the heterogeneity. Therefore, this paper attempts to fill this gap in the literature with an assessment of military spending with economic growth in the Middle East.

\section{Results and discussion:}

The paper checked the model specification for fixed versus random effect regression model for panel data. To test this hypothesis, this study used the Hausman test. It has set null hypothesis Ho: difference in coefficients not systematic. It has estimated the Hausman statistics for model selection, where b is consistent under Ho and $\mathrm{Ha}$; obtained from fixed effect and B is inconsistent under Ha, efficient under Ho; found from random effect model.

Table 1: Hausman test for Fixed Vs. Random Effect

\begin{tabular}{lcccc}
\hline & $\begin{array}{c}\text { Fixed effect } \\
(\mathrm{b})\end{array}$ & $\begin{array}{c}\text { Random effect } \\
(\mathrm{B})\end{array}$ & $\begin{array}{c}\text { Difference } \\
(\mathrm{b}-\mathrm{B})\end{array}$ & $\begin{array}{c}\text { Standard Error } \\
\text { sqrt(diag(V_b-V_B }))\end{array}$ \\
\hline Export (\% of GDP) & -0.01887 & -0.0220613 & 0.003193 & 0.002846 \\
Oil rent (\% of GDP) & -0.07355 & -0.0657984 & -0.00776 & 0.004577 \\
GDP growth rate (\%) & 0.060309 & 0.0584897 & 0.001819 &. \\
Crude-oil export (1000 metric tons) & $-2.99 \mathrm{E}-06$ & $2.71 \mathrm{E}-06$ & $-5.69 \mathrm{E}-06$ & $2.39 \mathrm{E}-06$ \\
\hline
\end{tabular}

Source: Author's calculation

Note: $\operatorname{chi} 2(4)=(\mathrm{b}-\mathrm{B})^{\prime}\left[\left(\mathrm{V}_{-} \mathrm{b}-\mathrm{V}_{-} \mathrm{B}\right)^{\wedge}(-1)\right](\mathrm{b}-\mathrm{B})=10.74$ and $\operatorname{Prob}>\mathrm{chi} 2=0.0296$

Hausman statistic explains a large and significant difference; therefore the paper rejects the null hypothesis. Hausman test statistics is significant; therefore it discards the random effects and will use the fixed effects instead. The study also finds that Prob $>$ chi2 $=0.0296$ (less than 0.05); therefore it will use fixed effect regression. Thus, it used Panel data fixed effect methods for this analysis. The advantage of fixed-effects (FE) method is that it controls for all the unobserved characteristics that are time invariant. For example, one country differs in agro-climatic conditions, culture, etc. The primary assumption of the FE model is that time-invariant characteristics are uncorrelated with the error term. With this assumption, the study will be able to eliminate the biases that may come across because of the correlation between the time-invariant characteristics and the error term. 
Table 2: Comparison of selected characteristics of critical variables

\begin{tabular}{|c|c|c|c|}
\hline & $\begin{array}{c}\text { Period 1 } \\
(1986-2001)\end{array}$ & $\begin{array}{c}\text { Period } 2 \\
(2002-2016)\end{array}$ & $\begin{array}{l}\text { T-test diff. } \\
\text { in means }\end{array}$ \\
\hline \multicolumn{4}{|l|}{ Middle East overall } \\
\hline Military expenditure ( $\%$ of GDP) & 7.08 & 4.34 & $4.81 * * *$ \\
\hline GDP growth (\%) & 4.64 & 4.13 & 0.75 \\
\hline Oil rent ( $\%$ of GDP) & 12.41 & 17.58 & $-3.90 * * *$ \\
\hline GDP per capita income (US \$) & 7070.40 & 15743.00 & $-7.70 * * *$ \\
\hline Export (\% of GDP) & 35.42 & 46.69 & $-6.70 * * *$ \\
\hline \multicolumn{4}{|c|}{ Countries with the export of crude oil above average } \\
\hline Military expenditure (\% of GDP) & 10.42 & 4.51 & $2.67 * * *$ \\
\hline GDP growth $(\%)$ & 5.63 & 3.93 & 0.86 \\
\hline Oil rent ( $\%$ of GDP) & 22.80 & 37.36 & $-7.54 * * *$ \\
\hline GDP per capita income (US \$) & 11300.00 & 19124.00 & $-3.90 * * *$ \\
\hline Export (\% of GDP) & 31.95 & 54.39 & $-7.32 * * *$ \\
\hline \multicolumn{4}{|c|}{ Countries with the export of crude oil below average } \\
\hline Military expenditure (\% of GDP) & 6.31 & 4.53 & $3.26^{* * *}$ \\
\hline GDP growth $(\%)$ & 4.30 & 4.36 & -0.09 \\
\hline Oil rent ( $\%$ of GDP) & 15.26 & 17.02 & -1.10 \\
\hline GDP per capita income (US \$) & 5143.80 & 15321.00 & $-4.67 * * *$ \\
\hline Export (\% of GDP) & 40.27 & 47.84 & $-2.58 * * *$ \\
\hline \multicolumn{4}{|c|}{ Countries with no export of crude oil } \\
\hline Military expenditure (\% of GDP) & 5.88 & 3.97 & $5.19 * * *$ \\
\hline GDP growth (\%) & 4.21 & 4.03 & 0.19 \\
\hline Oil rent ( $\%$ of GDP) & 0.02 & 0.02 & 1.17 \\
\hline GDP per capita income (US \$) & 6229.40 & 12959.00 & $-4.94 * * *$ \\
\hline Export (\% of GDP) & 32.28 & 37.65 & $-2.41 * *$ \\
\hline
\end{tabular}

Source: Author's estimate

Table 2 above shows the t-test difference in means across all the three categories on the basis of crude oil export. The research divided 30 years of data in two; each consisted of 15 years to show how things have changed across the Middle East. It sees a decline across all the three groups in military expenditure with the highest decline in countries where oil export is higher than the Middle East average. There is no significant change in GDP; however, across all the groups, there is an increase in GDP per capita income. This is the initial observation from the descriptive statics, and it will be explored in detail using the econometric results.

The impact of military spending on economic growth has been observed broadly in recent years. Defense expenditures have both costs and benefits. The costs of defense expenditures are mostly highlighted as opportunity costs, as it involves reductions in public and private spending and investment. It might have growth endorsing possible benefits: An increase in defense expenditure result in higher aggregate demand, production, and employment. Figure 1 plots the share of Military Expenditure and GDP per capita for the Middle East countries. The vertical axis shows the Military Expenditure (\% of GDP) as an indicator of conflict. The horizontal axis plots real GDP per capita. The graph shows mixed results. Oman has the highest share of military expenditure, and around 14 percent of GDP goes to the military expenditure, followed by Saudi Arabia which accounts for around 10 percent. Before a couple of years, Saudi Arabia had the highest share in the region. However, Oman has recently increased its share. 


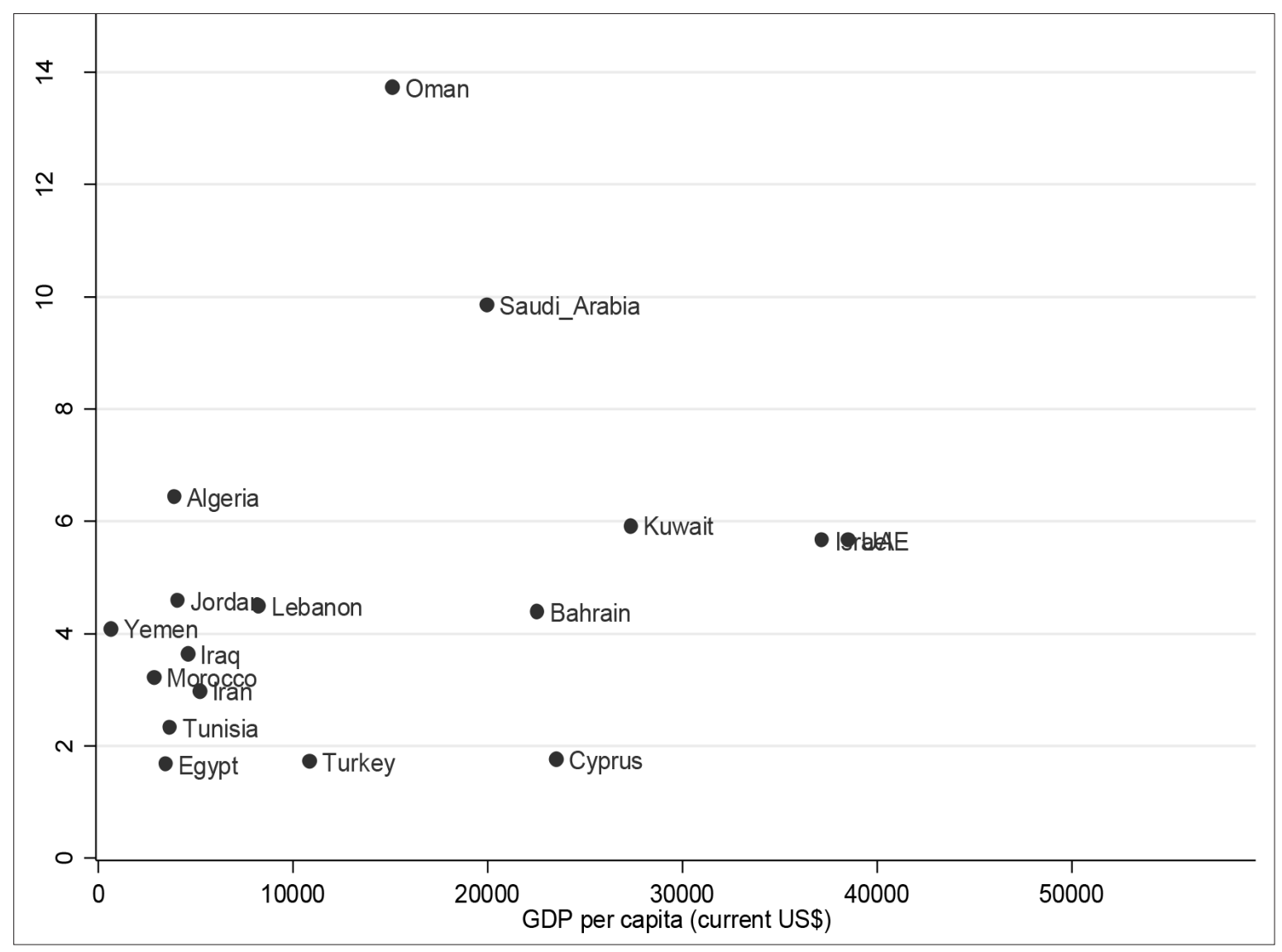

Figure 2: Military Expenditure and GDP Per Capita in the Middle East (2016)

Source: Author's calculation

What is striking in the figure is that most Middle East countries (except Tunisia, Egypt, Turkey, and Cyprus) have more than 2 percent of GDP to the Military Expenditure. It is also important to notice that countries with very low per capita have less share of Military Expenditure except for Algeria.

Moreover, countries with higher per capita GDP have military expenditure share to the GDP except for Cyprus, Bahrain, and others. It indicates both a negative and positive relationship exists between per capita income and Military Expenditure. It did not find any consistent association between these two. This graphical analysis is only indicative. It is not possible to infer the causal link from this graph. This study plotted the Military Expenditure (\% of GDP) across different periods to understand the growth in military spending share better. The figure below shows the military spending share for three periods throughout ten years. 


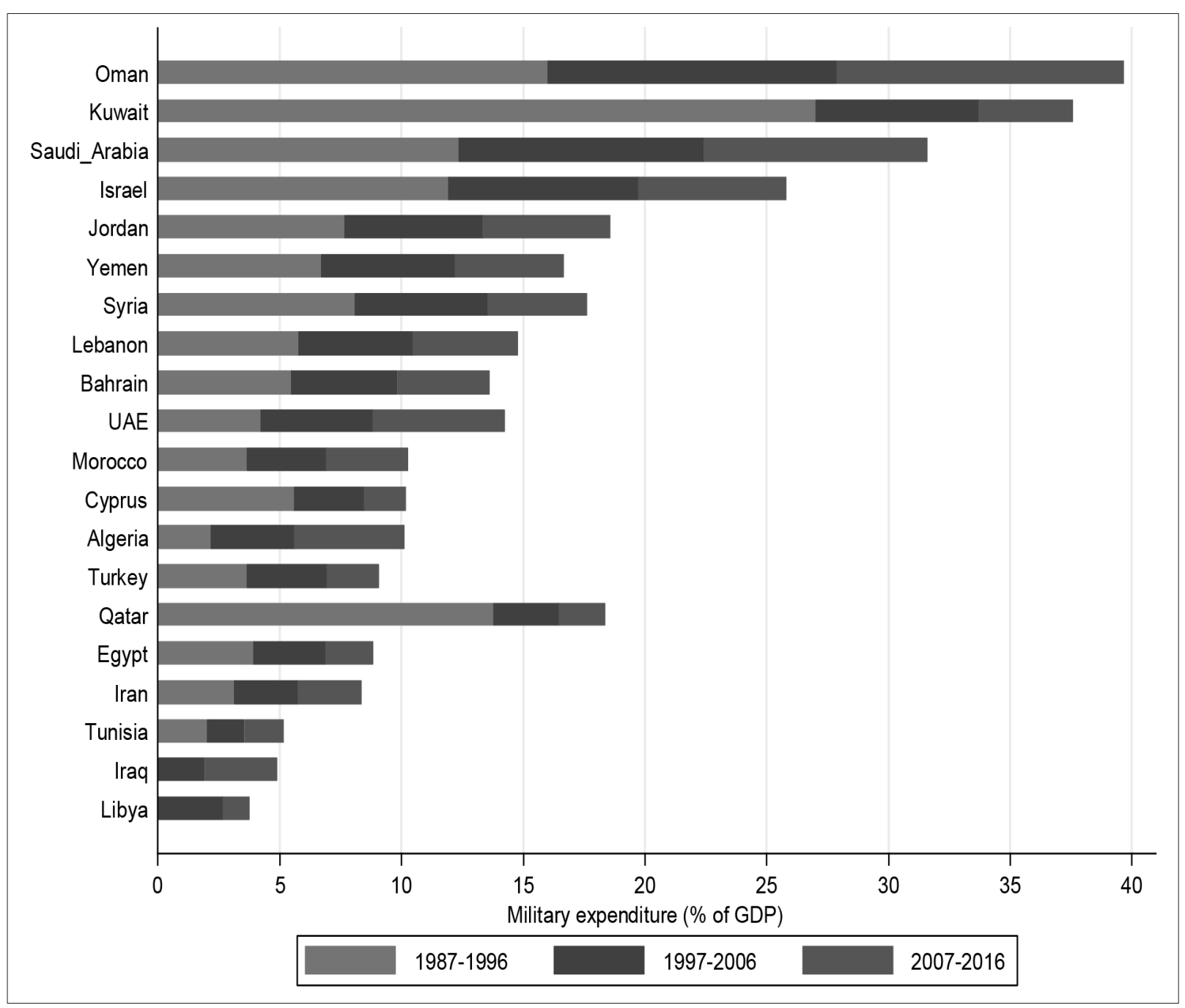

Figure 3: Military Expenditure (\% of GDP) across different periods

Source: Author's calculation

From the above figure 3, it shows the heterogeneity in military spending across countries for different periods. It reported the average military spending for each country for each phase of 10 years. Most countries have allocated more to military spending in the first phase (1987-1996) which includes Saudi Arabia, Oman, Qatar, Israel which is mainly because of the Gulf war, and Iraq invasion on Kuwait. However, for Iraq, there is no data available for that period. Later in the second phase (1997-2006), all these countries have reduced military spending. However, still countries like Saudi Arabia, Oman and Israel have kept a good share of military spending, while Qatar has reduced it drastically. In the third phase (2007-2016), it sees a sharp increase in military spending in Oman, and in the rest of the Middle Eastern countries, it is decreased or remain constant to the second phase. In general, there is a decline in military expenditure as a whole in the Middle East. To understand how the military spending affects the economic growth indicator, this research studied the association between Oil, Conflict, and Development in the next section in the panel framework using data on 20 Middle East countries from 1986-2016.

\section{Regression Strategy}

Based on table crude oil exports, the study classified Middle East countries into three categories; where the first group includes of those countries where average oil export is higher than the Middle East average. The second group comprises of those countries where average oil export is lower than Middle East average. The third group comprises of those countries where average oil export is almost zero. This strategy helps in empirically testing 
the role of oil in Middle East conflict.

Table 2: Country classification based on the export of crude oil in the Middle East

\begin{tabular}{|c|c|c|}
\hline Country & Crude Oil exports in (1000 metric tons) & Classification \\
\hline Saudi Arabia & 330042.2 & Above average \\
\hline UAE & 104020.4 & Above average \\
\hline Iran & 103777.9 & Above average \\
\hline Iraq & 67370.93 & Above average \\
\hline Kuwait & 65297.61 & Above average \\
\hline Libya & 49488.04 & Above average \\
\hline Oman & 35973.04 & Below Average \\
\hline Algeria & 26297.04 & Below Average \\
\hline Qatar & 25859.59 & Below Average \\
\hline Syria & 11179.52 & Below Average \\
\hline Yemen & 10219.85 & Below Average \\
\hline Egypt & 7314.407 & Below Average \\
\hline Bahrain & 3571.37 & Below Average \\
\hline Tunisia & 2894.593 & Below Average \\
\hline Cyprus & 0 & No Export \\
\hline Israel & 0 & No Export \\
\hline Jordan & 0 & No Export \\
\hline Lebanon & 0 & No Export \\
\hline Morocco & 0 & No Export \\
\hline Turkey & 0 & No Export \\
\hline
\end{tabular}

Note: Middle East average is 42165.32

Table 3: Middle East

\begin{tabular}{|c|c|c|c|c|c|}
\hline & (1) & (2) & (3) & (4) & (5) \\
\hline \multirow[t]{2}{*}{ Year (time trend) } & $-0.1743 * * *$ & $-0.1069 * * *$ & $-0.1399 * * *$ & $-0.1105^{* * *}$ & $-0.0633 * * *$ \\
\hline & $(0.0284)$ & $(0.0309)$ & $(0.0280)$ & $(0.0081)$ & $(0.0099)$ \\
\hline \multirow[t]{2}{*}{ Export (\% of GDP) } & & $-0.1359 * * *$ & & & 0.0033 \\
\hline & & $(0.0275)$ & & & $(0.0092)$ \\
\hline \multirow[t]{2}{*}{ Oil rents ( $\%$ of GDP) } & & & $-0.2450 * * *$ & & $-0.0408 * * *$ \\
\hline & & & $(0.0363)$ & & $(0.0139)$ \\
\hline \multirow[t]{2}{*}{ GDP growth (\%) } & & & & -0.0008 & 0.0035 \\
\hline & & & & $(0.0125)$ & $(0.0120)$ \\
\hline \multirow[t]{2}{*}{ GDP precipitate (Current US \$) } & & & & & $-0.0001 * * *$ \\
\hline & & & & & $(0.0000)$ \\
\hline \multirow[t]{2}{*}{ Constant } & $354.5636^{* * *}$ & $225.1436^{* * *}$ & $289.1538 * * *$ & $226.5052 * * *$ & $133.2373^{* * *}$ \\
\hline & $(56.8188)$ & $(61.4622)$ & $(55.8659)$ & $(16.1688)$ & $(19.6267)$ \\
\hline Number of Observation & 526 & 513 & 523 & 510 & 500 \\
\hline Log lik. & -1617.9247 & -1566.3751 & -1587.1973 & -903.8819 & -830.8389 \\
\hline Adj-R2 & 0.0326 & 0.0670 & 0.1119 & 0.2503 & 0.3622 \\
\hline
\end{tabular}

Source: Author's estimation 
Table 3 presents the result of the Middle East as a whole. The result of model 1 as specified in column 1 above, in which shows regressed the military expenditure with time trend after controlling country fixed effect, it is revealed that the Military expenditure is declining over the time. On average, in the past 30 years (1986-2016) military expenditure in the Middle East as a whole is declined by 5.22 percent of the total GDP. This is consistent with all the model specification, and results remain similar even after controlling other explanatory variables. The declining Military Expenditure can be interpreted as the reduction in the conflict in the Middle East from the earlier years. In model 2, the paper found a negative relationship between military expenditure and export (\% of GDP) and a one percent increase in military expenditure will reduce export by 13.5 percent. This is predictable as the increase in military expenditure causes a decrease in investments and exports and therefore delays the economic growth which means that there is an indirect adverse effect of military expenditure on real income. This result is consistent with the Heo (1999) for South Korea.

In model 3, it shows a negative association with oil rents (difference in the value of crude oil production at world prices and total costs of production) and the increase in military spending. As oil rents are considered as revenue from the oil industry, increase in military spending reduces the value of oil rents and hurts the economy. Similarly, for model 4, we did not find the significant coefficients for GDP and however in the final model with all the explanatory variables, it did not find the negative association with GDP per capita which shows an inverse relationship between development and conflict. Our results are consistent with the findings from earlier studies, (Yakolev Pavel 2007, Davis and Weinstein, 2002, Blomberg, Hess and Orphanides, 2004, and Barro, 2006; Abu-Bader, Sulaiman, et al. 2003) which shows that military burden negatively affects economic growth. However, it is revealed that military spending is declining over time. Therefore this indicates that as the country is developing, there is a reduction in conflict. It is crucial finding in the context and peace and development literature.

Table 4: Countries with the export of crude oil above average

\begin{tabular}{|c|c|c|c|c|c|}
\hline & $(1)$ & $(2)$ & (3) & (4) & (5) \\
\hline \multirow[t]{2}{*}{ Year (time trend) } & $-0.3632 * * *$ & -0.1445 & -0.1629 & $-0.1266 * * *$ & $-0.0488 * *$ \\
\hline & $(0.1138)$ & $(0.1346)$ & $(0.1238)$ & $(0.0206)$ & $(0.0234)$ \\
\hline \multirow[t]{2}{*}{ Export (\% of GDP) } & & $-0.2831 * * *$ & & & 0.0271 \\
\hline & & $(0.0840)$ & & & $(0.0173)$ \\
\hline \multirow[t]{2}{*}{ Oil rents ( $\%$ of GDP) } & & & $-0.3474 * * *$ & & $-0.1073 * * *$ \\
\hline & & & $(0.0915)$ & & $(0.0225)$ \\
\hline \multirow[t]{2}{*}{ GDP growth $(\%)$} & & & & -0.0091 & 0.0050 \\
\hline & & & & $(0.0221)$ & $(0.0198)$ \\
\hline \multirow[t]{2}{*}{ GDP per-capita (Current US \$) } & & & & & $-0.0001 * *$ \\
\hline & & & & & $(0.0000)$ \\
\hline \multirow[t]{2}{*}{ Constant } & $734.4845^{* * *}$ & 309.2987 & 344.3816 & $259.4033^{* * *}$ & $106.5591 * *$ \\
\hline & $(228.0136)$ & $(267.7166)$ & $(246.7803)$ & $(41.3660)$ & $(46.4886)$ \\
\hline Number of Observation & 136 & 131 & 134 & 130 & 121 \\
\hline Log lik. & -503.5814 & -481.4447 & -489.6855 & -253.6736 & -201.1229 \\
\hline Adj-R2 & 0.0300 & 0.1071 & 0.1250 & 0.1928 & 0.4713 \\
\hline
\end{tabular}

Source: Author's estimation

Note: Standard errors are in parenthesis, and $* * *, * *$ and $*$ denotes significance at 1, 5 and 10 percent respectively.

Table 4 presents the result for the countries whose average oil export is higher than the average Middle East export. In model 1, it shows a significant reduction in military spending over time. The estimates show that in the last 30 years military spending is declined by almost 11 percent (almost double reduction in military spending compare to all Middle Eastern countries). This is expected as; in countries where oil is abundant, conflict is less persistent. In model 2 and 3, it also found a negative association between an increase in military 
expenditure and export and oil rents. However, the coefficients are much more significant than the Middle East as a whole. It suggests that oil-rich exporting countries in the region are severely affected by the increase in military spending. This is possibly due to almost all major oil export nations all have large income-producing oil export sectors. This hinders economic growth due to the reduction in investment and exports. The study finds insignificant coefficients for GDP growth; however its significant and negative for GDP per capita with an increase in military spending, which shows that military burden negatively and affects economic growth and GDP per capita.

Table 5: Countries with the export of crude oil below average

\begin{tabular}{|c|c|c|c|c|c|}
\hline & (1) & (2) & (3) & (4) & (5) \\
\hline \multirow[t]{2}{*}{ Year (time trend) } & $-0.1118^{* * *}$ & $-0.0654 * * *$ & $-0.1114 * * *$ & $-0.0738 * * *$ & $-0.0472 * * *$ \\
\hline & $(0.0156)$ & $(0.0125)$ & $(0.0157)$ & $(0.0125)$ & $(0.0150)$ \\
\hline \multirow[t]{2}{*}{ Export ( $\%$ of GDP) } & & -0.0165 & & & -0.0169 \\
\hline & & $(0.0116)$ & & & $(0.0160)$ \\
\hline \multirow[t]{2}{*}{ Oil rents ( $\%$ of GDP) } & & & -0.0220 & & 0.0051 \\
\hline & & & $(0.0229)$ & & $(0.0238)$ \\
\hline \multirow[t]{2}{*}{ GDP growth (\%) } & & & & 0.0163 & 0.0323 \\
\hline & & & & $(0.0244)$ & $(0.0259)$ \\
\hline \multirow[t]{2}{*}{ GDP per capita (Current US \$) } & & & & & $-0.0001 * *$ \\
\hline & & & & & $(0.0000)$ \\
\hline \multirow[t]{2}{*}{ Constant } & $229.1895 * * *$ & $136.6781 * * *$ & $228.6082 * * *$ & $152.8619 * * *$ & $100.5101^{* * *}$ \\
\hline & $(31.1475)$ & $(24.8568)$ & $(31.4651)$ & $(24.9470)$ & $(29.8850)$ \\
\hline Number of Observation & 212 & 205 & 211 & 203 & 202 \\
\hline Log lik. & -430.2393 & -352.5362 & -428.1949 & -351.6767 & -344.4241 \\
\hline Adj-R2 & 0.1713 & 0.1180 & 0.1699 & 0.1223 & 0.1361 \\
\hline
\end{tabular}

Source: Author's estimation

Note: Standard errors are in parenthesis, and $* * *, * *$ and $*$ denotes significance at 1,5 and 10 percent respectively.

Table 5 presents the result for the countries whose average oil export is below than average Middle East export. It shows that Military expenditure is declining over time and it declined by around 3.4 percent in the last 30 years. This shows the heterogeneity in reduction, and it is much lesser than the whole Middle East region and the countries where crude oil export is above than the Middle East average. This is probably because these nations incurred less on defense spending and their reason may be that they have lesser oil exports in the region, therefore have lesser income from producing oil export sectors. It does not find any significant association for exports and oil rents. The study finds negative and significant coefficients for GDP per capita. This indicates that there exists an opposite relationship between development and conflict which expresses that as we are developing our conflict is reducing.

Table 6: Result for the countries with no oil export

\begin{tabular}{|l|c|c|c|c|c|}
\hline & $(1)$ & $(2)$ & $(3)$ & $(4)$ & $(5)$ \\
\hline Year (time trend) & $-0.1310^{* * *}$ & $-0.1412^{* * *}$ & $-0.1353^{* * *}$ & $-0.1380^{* * *}$ & $-0.0615^{* * *}$ \\
\hline & $(0.0112)$ & $(0.0117)$ & $(0.0117)$ & $(0.0108)$ & $(0.0162)$ \\
\hline Export (\% of GDP) & & 0.0117 & & & -0.0101 \\
\hline Oil rents (\% of GDP) & & $(0.0148)$ & & & $(0.0134)$ \\
\hline & & & -6.6017 & & -2.2344 \\
\hline GDP growth (\%) & & & $(5.2037)$ & & $(4.3915)$ \\
\hline & & & & -0.0061 & -0.0177 \\
\hline
\end{tabular}




\begin{tabular}{|l|c|c|c|c|c|}
\hline GDP per capita (Current US \$) & & & & $-0.0002 * * *$ \\
\hline Constant & & & & & $(0.0000)$ \\
\hline & $267.0675 * * *$ & $287.2654 * * *$ & $275.9725 * * *$ & $281.2773 * * *$ & $130.2054 * * *$ \\
\hline Number of Observation & $(22.4210)$ & $(23.1834)$ & $(23.4560)$ & $(21.6952)$ & $(32.1446)$ \\
\hline Log lik. & 178 & 177 & 178 & 177 & 177 \\
\hline Adj-R2 & -293.1725 & -280.7423 & -292.3339 & -281.0170 & -255.7933 \\
\hline
\end{tabular}

Source: Author's estimation

Note: Standard errors are in parenthesis, and $* * *, * *$ and $*$ denotes significance at 1,5 and 10 percent respectively.

Table 6 represents the regression model for countries where they do not export oil to any other nation. The results show that military spending is also decreasing over time. It has declined by around 4 percent in the past three decades (1986-2016). The study does not find any significant effect on exports, oil rents and GDP growth. However, it finds an adverse effect of military expenditure on GDP per capita and the effect is much larger than countries with abundant oil resources. This indicates that there is an inverse relationship between development and conflict.

Our conjecture is that the change in oil prices may affect military expenditure. Though the oil prices remain fixed for all the countries it may affect countries differently depending on the country export and import relation as well as other observable and unobservable factors. However, with the given panel data we are using we do find variation in oil prices across all the categories and therefore we explore the association between oil prices and military expenditure. Figure 4 shows the Locally Weighted Scatterplot Smoothing (LOWESS) graph which shows the trends in oil prices for the given time period and in table 7, explores the association between oil prices and military expenditure.

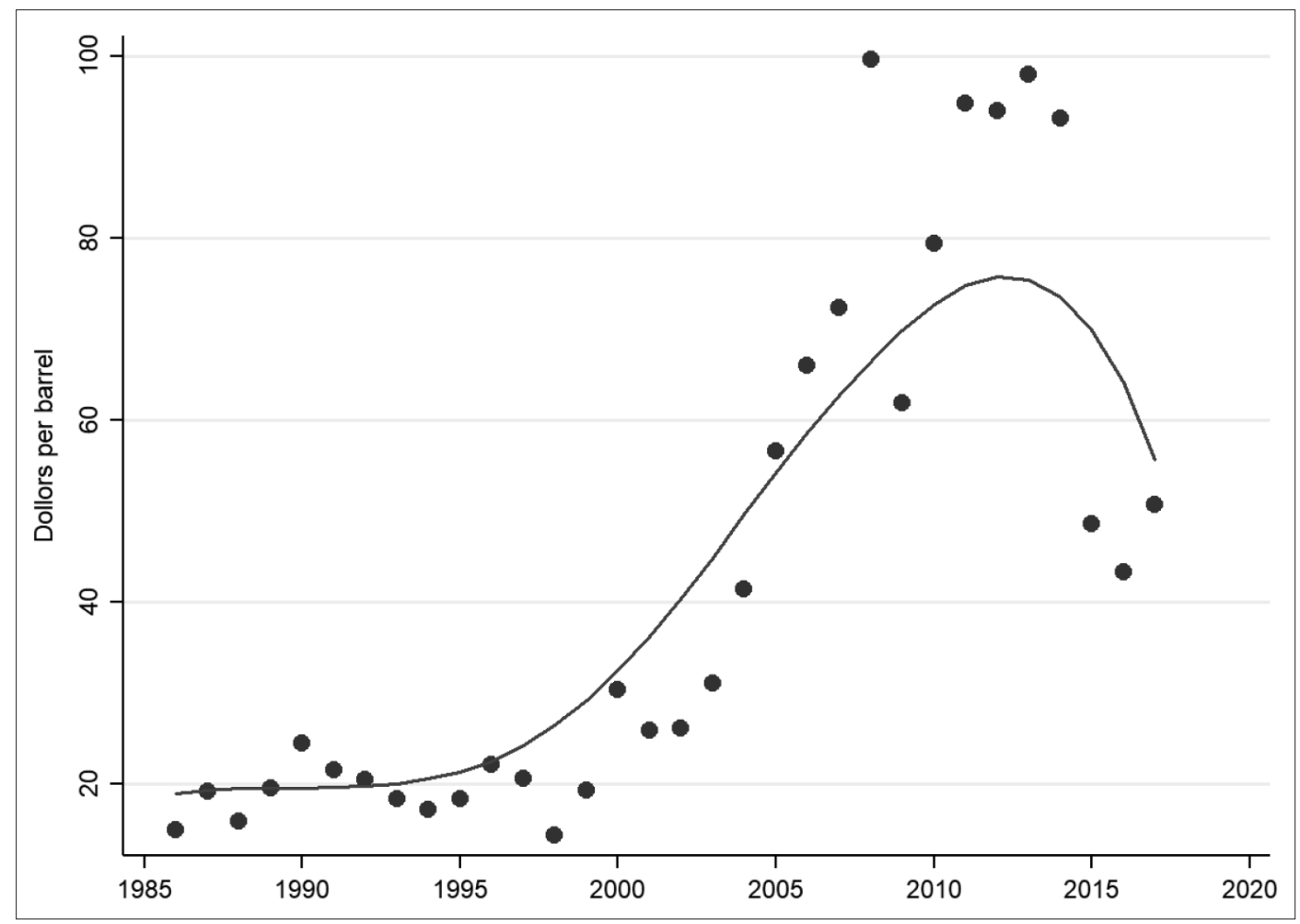

Figure 4: Oil prices (USD per barrel) from 1986-2016

Source: Authors' calculation 
Table 7: Association between oil prices and military expenditure

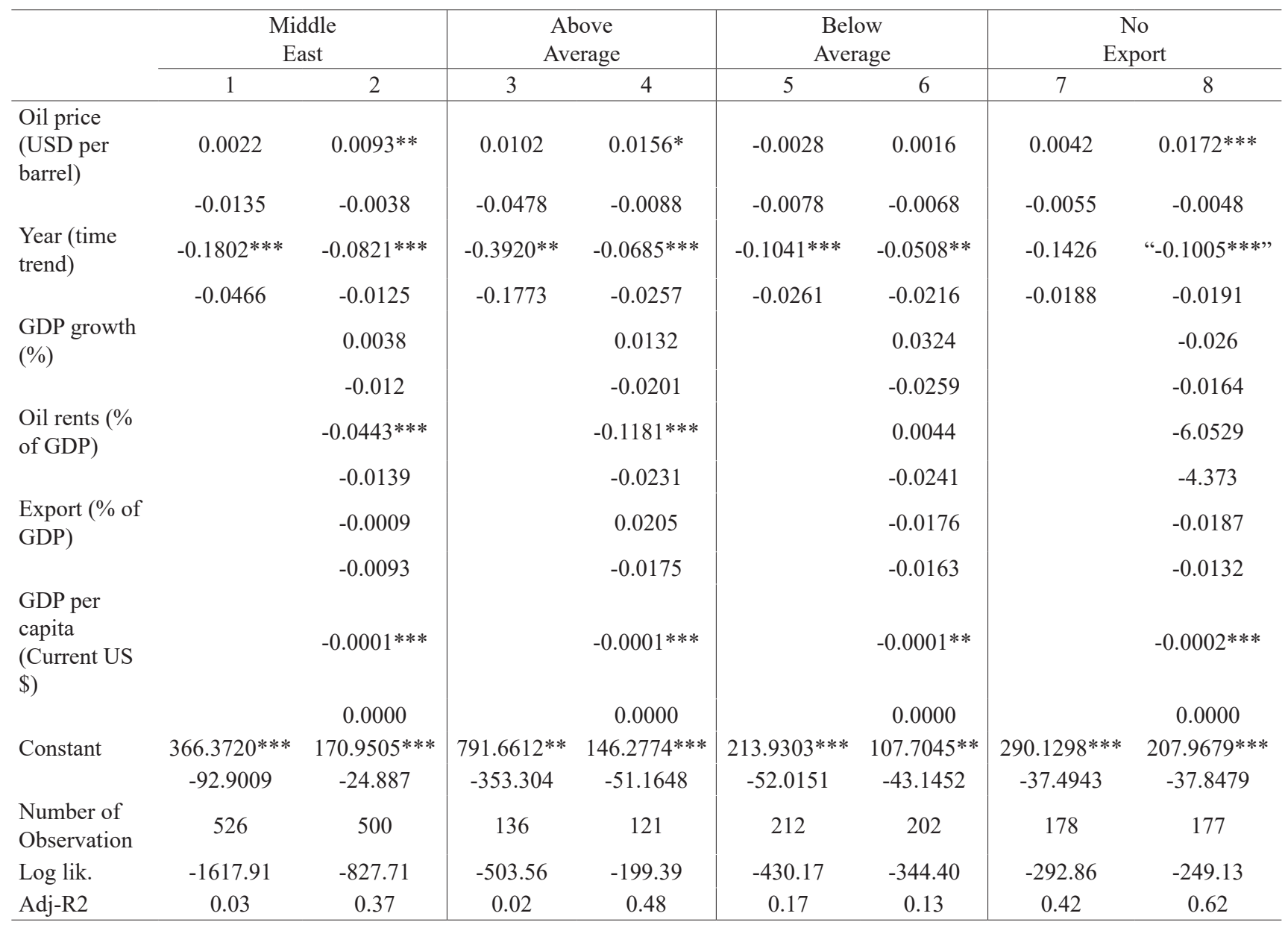

Source: Author's estimation

Note: Standard errors are in parenthesis, and $* * *, * *$ and $*$ denotes significance at 1,5 and 10 percent respectively.

Figure 4 shows the change in oil prices and dotted points on the curve shows the year to year fluctuations while the smooth red line shows the LOWESS graph. Oil prices information obtained from U.S. Energy Information Administration. Oil prices after 2000 increased significantly and the greatest increased observed after 2009 and 2010, however, after 2013, there is a sharp decline in the oil prices that may affect the military expenditure. Therefore, we explore the association between oil prices and military expenditure using panel data fixed effect model. The results show that both oil prices and military expenditure have a positive association controlling for country and year fixed effect across all countries classification based on oil export. In a simple regression with just oil prices, the association is positive with military expenditure but not significant. However, in the final model where we add all the control variables, we see a positive and significant association between oil price and military expenditure. The results show that one dollar (per barrel) increase in oil prices increase military expenditure by roughly 1 percent in middle east region and greatest increase observed in the countries where oil export is greater than the middle east average (1.5 percent) and while for countries with no oil export it is 1.7 percent increase in military expenditure. We do not see any significant effect in the countries with oil export below than middle east average. This result is expected as the revenues generated from oil exports will have a greater influence on government expenditure for different economic and social sectors. 


\section{Conclusions}

Military spending by governments influence the resources it takes up, particularly when it leads to or facilitates conflicts. Whereas countries also need some level of security to deal with internal and external intimidations, these have opportunity costs, as they avoid resources being used for other purposes that strengthen the pace of development. Our primary purpose of this analysis is to see the causal relationship between government expenditure and economic development in Middle East region, where governments play essential characters in economies, and large sizes of spending go to the military. The panel data methods are used for the moderately long time series (1986-2016) which gives a better understanding than simple cross-sections on averages. The study finds evidence of a relationship between conflict and development in the Middle East region, which indicates a negative relationship between GDP per capita and Military Expenditure. Most of the previous studies indicate that the relationship between development and conflict will not be uniform throughout regions and country in this present world. To test this hypothesis, the study categorized oil exporting countries into three groups' countries with above average oil export, below average oil export and no export. We also found that in previous literature that; change in GDP and military expenditure is affected by a myriad of factors; therefore, this study clearly acknowledges the limitations as there may exist many observable and unobservable factors that may affect development indicators.

In all the three categories and the Middle East, the study finds that a significant reduction in military spending over time. This declining military expenditure in all the categories can be interpreted as the reduction in the conflict in the Middle East from the previous years. A significant decline was observed in the countries where oil export is above average than the Middle East. The study also found that on an average in the past 30 years military expenditure in the Middle East is declined by (5.22 percent) of the total GDP followed by Countries with the export of crude oil above average declined by approx. (11 percent) moreover, countries with the export of crude oil below average are declined by ( 3.4 percent), and Countries with no export of crude oil declined by (4 percent).

The study suggests that a heterogeneous relation between an increase in military spending and with both exports and oil rents in all the above-specified model based on the export of crude oil. There is a significant inverse relationship between the military spending with exports and oil rents in overall Middle East analysis and for countries whose average oil export is greater than the Middle East. The negative coefficients between the military spending with exports and oil rents are much bigger for countries with whose oil export is above average than the Middle East. This is possibly due to the increase in military expenditure causes a decrease in investments and exports and therefore delays the economic growth. Similarly, it is observed that there is a negative association with oil rents and conclude that the increase in military spending reduces the value of oil rents and hurts the economy. It suggests that oil-rich exporting countries in the region are severely affected by the increase in military spending. This is possibly due to almost all major oil export nations all have large income-producing oil export sectors. However, it does not find any significant relationship between military spending with exports and oil rents in countries whose oil export is below average than the Middle East and countries with no export of crude oil. We also look at the oil prices as any change in oil prices may affect revenues and consequently on government spending. We see that oil prices after 2000 increased significantly and the greatest increased observed after 2009 and 2010, however, after 2013, there is a sharp decline in the oil prices that may affect the military expenditure. Our results show that both oil prices and military expenditure have a positive association controlling for country and year fixed effect across all countries classification based on oil export.

Across all the model specification the study finds the negative association with the increase in military spending and GDP per capita, which shows an inverse relationship between development and conflict. The effect is much stronger in the case of countries no export of crude oil. Our finding is consistent with the earlier studies, (Yakolev Pavel 2007, Davis and Weinstein, 2002, Blomberg, Hess and Orphanides, 2004, and Barro, 2006; Abu-Bader, Sulaiman, et al. 2003) which shows that military burden negatively affects economic development. The study also finds that military spending is declining over time. Therefore, this indicates that as the country is developing, there is a reduction in conflict. It is a crucial finding in the context of peace and development literature. 


\section{References}

Abu Al-Foul, B.M. (2014). Military Spending and Economic Growth: Evidence from Jordan. American University of Sharjah, School of Business Administration Working Paper Series, Working Paper 19-04/2014.

Abu-Bader, S. \& Abu-Qarn, A.S. (2003). Government expenditures, military spending, and economic growth: causality evidence from Egypt, Israel and Syria. Journal of Policy Modelling 25: 567-583.

Abu-Ghunmi, D., \& Larkin, C. (2016). The economic opportunity cost for countries located in crisis zones: Evidence from the Middle East. Research in International Business and Finance, 36: 532-542.

Addison, T., Chowdhury, A. R., \& Murshed, S. M. (2002). By how much does conflict reduce financial development? (No. 2002/48). WIDER Discussion Papers//World Institute for Development Economics (UNU-WIDER).

Ades, A., \& Chua, H. B. (1997). Thy neighbor's curse: regional instability and economic growth. Journal of Economic Growth, 2(3): 279-304.

Al-Jarrah, M.A. (2005), Defense spending and economic growth in an oil-rich country the case of Saudi Arabia. Pakistan Economic and Social Review, XLIII(2): 151-166.

Basedau, M., \& Lay, J. (2009). Resource curse or rentier peace? The ambiguous effects of oil wealth and oil dependence on violent conflict. Journal of Peace Research, 46(6): 757-776.

Benoit, E. (1973). Defense and Economic Growth in Developing Countries, Lexington: Lexington Books.

Bodea, C., Higashijima, M., \& Singh, R. J. (2016). Oil and Civil Conflict: Can Public Spending Have a Mitigation Effect?. World Development, 78: 1-12.

Brzoska, M. (1983). Research communication: The military-related external debt of Third World countries. Journal of Peace Research, 20(3), 271-277.

Chaudhry, Kiren Aziz. (1997). The Price of Wealth: Economics and Institutions in the Middle East. Ithaca, N.Y.: Cornell University Press.

Coleman, L. (2012). Explaining crude oil prices using fundamental measures. Energy Policy, 40; 318-324.

Collier, P. (1999). On the economic consequences of civil war. Oxford economic papers, 51(1); 168-183.

Das, S., Leiby, P. N., Lee, R., Hadder, G. R., \& Davis, R. M. (1990). Oil markets under political and military stress. Energy Economics, 12(3): 204-210.

De Groot, O. J. (2010). The spillover effects of conflict on economic growth in neighbouring countries in Africa. Defense and Peace Economics, 21(2), 149-164.

De Rouen, K. (2000). The guns-growth relationship in Israel. Journal of Peace Research 37(1): 69-83.

Duella, A. (2014). Military burden and economic growth: Evidence from a multivariate cointegration analysis. Journal of Global Economics, 2: 119. https://doi.org/10.4172/economics.1000119

Dunne, J. P., \& Tian, N. (2015). Military expenditure, economic growth, and heterogeneity. Defense and Peace Economics, $26(1)$ : 15-31.

Dunne, J. P., Nikolaiodu, E. \& Voguas, D. (2001) Defence spending and economic growth: a causal analysis for Greece and Turkey. Defense and Peace Economics, Special Issue 12(1): 5-26.

Dunne, J.P., \& Uye, M. (2010) Military spending and development. In The Global Arms Trade., edited by A. Tan. London: Routledge, 293-305.

Dunne, P.J. \& Tian, N. (2013) Military expenditure and economic growth: A survey. The Economics of Peace and Security Journal 8(1): 5-11.

Dźwigoł, H.; Dźwigoł-Barosz, M.; Zhyvko, Z.; Miśkiewicz, R.; Pushak, H. (2019). Evaluation of the energy security as a component of national security of the country, Journal of Security and Sustainability Issues 8(3): 307-317. http://doi.org/10.9770/jssi.2019.8.3(2)

F. Gregory Gause III, Oil Monarchies: Domestic and Security Challenges in the Arab Gulf States (New York: Council on Foreign Relations Press, 1994): p 44 
Fattouh, B., \& Darbouche, H. (2011). The implications of the Arab uprisings for oil and gas markets. Oxford Institute for Energy Studies.

Guliyeva, A., Britchenko, I., \& Rzayeva, U. (2018). Global security and economic asymmetry: a comparison of developed and developing countries, Journal of Security and Sustainability Issues 7(4): 707-717. https://doi.org/10.9770/jssi.2018.7.4(8)

Gupta, S., Clements, B., Bhattacharya, R., \& Chakravarti, S. (2004). Fiscal consequences of armed conflict and terrorism in low-and middle-income countries. European Journal of Political Economy, 20(2): 403-421.

Haque, M. I., \& Khan, M. R. (2019). Role of Oil Production and Government Expenditure in Improving Human Development Index: Evidence from Saudi Arabia. International Journal of Energy Economics and Policy, 9(2): 251-256.

Hegre, H., \& Sambanis, N. (2006). Sensitivity analysis of empirical results on Civil War Onset. Journal of Conflict Resolution, 50(4), 508-535.

Henderson, E. A., \& Singer, J. D. (2000). Civil war in the post-colonial world, 1946-92. Journal of Peace Research, 37(3): $275-299$.

Heo, U. (1999). Defense spending and economic growth in South Korea: The indirect link. Journal of Peace Research, 36(6): 699-70

Humbatova, S. I. O.; Garayev, A.I.O.; Tanriverdiev, S.M.O.; Hajiyev, N.Q-O. 2019. Analysis of the oil, price and currency factor of economic growth in Azerbaijan, Entrepreneurship and Sustainability Issues 6(3): 1135-1153. http://doi.org/10.9770/jesi.2019.6.3(20)

Ji, Q., \& Guo, J. F. (2015). Oil price volatility and oil-related events: An Internet concern study perspective. Applied Energy, 137: 256-264.

Karagol, E. (2006). The relationship between external debt, defense expenditures, and GNP revisited: The case of Turkey. Defense and Peace Economics, 17(1): 47-57.

Katina, J., Sansyzbayeva, G. N., Guliyeva, A.\&Rzayeva, U. (2018). Threats to the country's sustainable economic development: a case study, Journal of Security and Sustainability Issues 8(1): 113-122. https://doi.org/10.9770/jssi.2018.8.1(10)

Khan, Riyazuddin. (2015). A Spatial Political Analysis of Regional Conflict of Middle East. University of Delhi.

Kharlamova G., Nate S., Chernyak O. (2016), 'Renewable energy and security for Ukraine: challenge or smart way?', Journal of International Studies, 9(1): 88-115. https://doi.org/10.14254/2071-8330.2016/9-1/7

Kazansky, R.\& Andrassy, V. 2019. Conflict resolution approaches towards smart sustainability of internal relations, Entrepreneurship and Sustainability Issues 6(3): 1468-1484. https://doi.org/10.9770/jssi.2019.6.3(29)

Lebovic, J. H. \& Ishaq, A. (1987) Military burden security needs and economic growth in the Middle East. Journal of Conflict Resolution 31(1): 106-138.

Looney, R. E., \& Frederiksen, P. C. (1986). Defense expenditures, external public debt, and growth in developing countries. Journal of Peace Research, 23(4): 329-337.

Masood, O., Tvaronavičienè, M., Javaria, K. 2019. Impact of oil prices on stock return: evidence from G7 countries, Insights into Regional Development 1(2): 129-137. https://doi.org/10.9770/ird.2019.1.2(4)

OPEC (2017). Organization of the Petroleum Exporting Countries (OPEC), Annual Statistical Bulletin, 52nd edition. https://www.opec. org/opec_web/static_files_project/media/downloads/publications/ASB2017_13062017.pdf

Pietrzak, M.B., Balcerzak, A. P., Gajdos, A., Arendt, Ł (2017). Entrepreneurial environment at regional level: the case of Polish path towards sustainable socio-economic development, Entrepreneurship and Sustainability Issues 5(2): 190-203. http://doi.org/10.9770/ jesi.2017.5.2(2)

Prakash, R. \& Garg, P. 2019. Comparative assessment of HDI with Composite Development Index (CDI), Insights into Regional Development 1(1): 58-76. http://doi.org/10.9770/IRD.2019.1.1(5)

Prause, G. Tuisk, T. \& Olaniyi. 2019. Between Sustainability, Social Cohesion and Security Regional Development in North-Eastern Estonia, Entrepreneurship and Sustainability Issues 6(3): 1235-1254. http://doi.org/10.9770/jesi.2019.6.3(13)

Račkauskas, M., \& Liesionis, V. (2013). The relationship between government expenditure and public safety in Lithuania, Journal of Security and Sustainability Issues 3(2): 31-40. htpp://dx.doi.org/10.9770/jssi.2013.3.2(3)

Rogalev, A., Komarov, I., Kindra, V., Zlyvk, O. (2018). Entrepreneurial assessment of sustainable development technologies for power energy sector. Enterpreneurship and Sustainability Issues 6(1): 429-445. http://doi.org/10.9770/jesi.2018.6.1(26) 
Sab, M. R. (2014). Economic Impact of Selected Conflicts in the Middle East: What Can We Learn from the Past? (No. 14-100). International Monetary Fund.

Schwarz, R. (2008). The political economy of state-formation in the Arab Middle East: Rentier states, economic reform, and democratization. Review of International Political Economy, 15(4), 599-621.

Sdralevich and others, (2013), Iraq: Article IV Consultation, IMF Staff Country Report No. 13/217 (Washington: International Monetary Fund). https://www.imf.org/external/pubs/ft/scr/2013/cr13217.pdf

Serkan, K., Hopoglu, S., \& Bozma, G. (2016). Conflict, Defense Spending and Economic Growth in the Middle East: A Panel Data Analysis. International Journal of Economics and Financial Issues, 6(1): 80-86.

Sezgin, S. (2000) An empirical analysis of Turkey's defense-growth relationships with a multi-equation model (1956-1994). Defense and Peace Economics 11(1): 63-80.

Shevyakova, A. \& Petrenko, E. (2018). Threats to the security of a country: revealing Negative trends in the development of human capital, Journal of Security and Sustainability Issues 8(2): 277-288. https://doi.org/10.9770/jssi.2018.8.2(14)

Smaliukiene, R. (2018). Sustainability issues in the military: genesis and prospects, Journal of Security and Sustainability Issues 8(1): 19-32. https://doi.org/10.9770/jssi.2018.8.1(2)

Smyth, R., \& Kumar Narayan, P. (2009). A panel data analysis of the military expenditure-external debt nexus: Evidence from six Middle Eastern countries. Journal of Peace Research, 46(2): 235-250.

Stukalo, N., Steblianko, I., Simakhova, A., Doroshkevych, V. (2018). Trends in economic and social security at national and European level: interrelationships, threats and opportunities, Journal Security and Sustainability Issues, 8(2): 199-208. http://doi.org/10.9770/ jssi.2018.8.2(7)

Sulphey, M. M.; Alkahtani, N. S. (2017). Economic security and sustainability through social entrepreneurship: the current Saudi scenario, Journal of Security and Sustainability Issues 6(3): 479-490. http://dx.doi.org/10.9770/jssi.2017.6.3(12)

Taydes, Z., \& Peksen, D. (2012). Can states buy peace? social welfare spending and civil conflicts. Journal of Peace Research, 49(2), 273-287.

Tian, N., Fleurant, A., Kuimova, A., Wezeman, P. D., \& Wezeman, S. T. (2018). Trends in world military expenditure, 2017. Stockholm International Peace Research Institute.

Traversari, R., Den Hoed, M., Di Giulio, R. and Bomhof, F. (2017). Towards sustainability through energy efficient buildings design: semantic labels, Entrepreneurship and Sustainability Issues, 4(3): 243-256. https://doi.org/10.9770/jesi.2017.4.3S(1)

Tvaronavičienè, M. (2018). Toward efficient policy making: forecasts of vulnerability to external global threats, Journal of Security and Sustainability Issues 7(3): 591-600. https://doi.org/10.9770/jssi.2018.7.3(18)

Yildirim, J., Sezgin, S., \& Öcal, N. (2005). Military expenditure and economic growth in Middle Eastern countries: A dynamic panel data analysis. Defense and Peace Economics, 16(4): 283-295.

Yousef, T. M. (2004). Development, growth and policy reform in the Middle East and North Africa since 1950. Journal of Economic Perspectives, 18(3): 91-115.

Zeibote, Z. (2019). The impact of globalization on regional development and competitiveness: cases of selected regions, Insights into Regional Development 1(1): 33-47. http://doi.org/10.9770/IRD.2019.1.1(3)

Zhang, X., Yu, L., Wang, S., \& Lai, K. K. (2009). Estimating the impact of extreme events on crude oil price: An EMD-based event analysis method. Energy Economics, 31(5): 768-778. 
Md Riyazuddin Khan is an Assistant Professor in the Department of Geography at Bhim Rao Ambedkar College, University of Delhi. He has his Ph.D from the Department of Geography, Delhi School of Economics, University of Delhi. Mr. Khan has contributed many articles and research paper to various International and National Journals. His major fields of specialization are political geography and regional studies, Issues and Challenges of Middle East, Africa and South Asia.

ORCID ID: orcid.org/0000-0001-5829-3721

Mohammad Imdadul Haque is an Associate Professor and Head of Management Department, College of Business Administration at Prince Sattam Bin Abdulaziz University, Kingdom of Saudi Arabia. He is a Ph.D. in Economics from Aligarh Muslim University, India. $\mathrm{He}$ has around two dozen research papers in peer-reviewed journals of international repute; delivered research papers at over half a dozen national and international conferences; and another half a dozen funded university projects to his credit. He has a rich experience of using software like SPSS, Stata, and Eviews for both multivariate analysis and econometric analysis. His research interests are macroeconomics and developmental economics

ORCID ID: orcid.org/0000-0001-6323-032X 